\title{
IMPACT OF WATER DEFICIT IN THE RELATIONSHIP AMONG ALFALFA TRAITS
}

\author{
IMPACTO DO DÉFICIT DE ÁGUA NA RELAÇÃO ENTRE CARACTERES DE \\ ALFALFA
}

\author{
Iara Gonçalves dos SANTOS; Paulo Eduardo TEODORO ${ }^{2 *}$; Cosme Damião CRUZ; \\ Reinaldo de Paula FERREIRA ${ }^{3}$ \\ 1. Universidade Federal de Viçosa, Viçosa, MG, Brasil. 2. Universidade Federal de Mato Grosso do Sul, Chapadão do Sul, MS, Brasil; \\ 3. Embrapa Gado de Leite, Juiz de Fora, MG, Brasil. * eduteodoro@hotmail.com
}

\begin{abstract}
This study aimed to evaluate the relationship among traits related to yield and nutritive value of alfalfa genotypes grown under deficit and full irrigation conditions. Seventy-seven alfalfa genotypes were evaluated in two different cuts, the first one with full irrigation, and the second, with water deficit. A randomized block design with three replications was used. The evaluated traits were vigor, plant height, dry matter biomass, stem-to-leaf ratio, dry matter percentage, leaf and stem protein contents, in vitro dry matter digestibility, neutral detergent fiber, acid detergent fiber, and lignin. Significant interaction between genotypes and environments was reported for vigor, plant height, and lignin. The correlation between traits and path analysis of dry matter biomass was performed for each cut, aiming to identify auxiliary traits for indirect selection. Water availability did not alter the phenotypic and genotypic correlations, only their magnitudes. Regardless of the environment, plant height is one of the most promising traits for the selection of alfalfa genotypes with higher dry matter biomass since it showed a high direct effect in the same sense of its phenotypic correlations. However, the coefficient of determination obtained by the model applied to full irrigation was higher than that of the water-deficit environment, indicating the importance of variables not included in this study in the determination of alfalfa dry matter biomass under dry conditions.
\end{abstract}

KEYWORDS: Medicago sativa. Path analysis. Correlations. Dry matter biomass.

\section{INTRODUCTION}

Alfalfa (Medicago sativa L.) is one of the most important forage plants in temperate climate countries (ANNICCHIARICO et al., 2015; FERREIRA et al., 2008), either by the range of explored area, or by its interesting traits, such as high productivity and protein content, which guarantees the culture the possibility of using in the feeding of specialized dairy herds, with excellent results in milk production (COMERON t al., 2015). For being a legume with a deep root system, alfalfa avoids soil erosion and increases soil fertility by fixing about $135-605 \mathrm{~kg} \mathrm{ha}^{-1}$ of nitrogen per year (ARSHAD, et al., 2017).

Although alfalfa has potential for cultivation in regions with different soil and climatic conditions (VIANA et al., 2004), in Brazil, 90\% of alfalfa production are concentrated in the southern region, mainly in the states of Paraná and Rio Grande do Sul (FERREIRA; VILELA, 2015). The factors that limit the use of alfalfa in productive systems are related to the lack of knowledge of cultivation techniques and the low availability of cultivars adapted to tropical conditions (BOTREL et al.,
2001; FERREIRA; VILELA, 2015). In addition, abiotic stresses, especially drought, affect forage development and productivity.

About $80 \%$ of the world's water resources are used in agriculture and, with current estimates of population growth worldwide, agriculture will have to produce more with less water (ZHANG et al., 2015). Therefore, one of the greatest challenges to breeders in the coming decades will be to develop cultivars tolerant to drought (CABELLO et al., 2017). Several studies related to alfalfa drought tolerance have been developed in recent years. Zhang et al. (2017) investigated the genetic diversity and phenotypic variation for drought tolerance in alfalfa germplasm; Archad et al. (2017) examined the response of transgenic alfalfa plants that super expressed the miR156 microRNA from drought tolerance; Molor et al. (2016) performed a comparative analysis of morphological and physiological parameters and selection of droughttolerant cultivars; Qiao-li et al. (2015) performed proteomic analysis to evaluate drought stress on seedlings; and Zhang et al. (2015) identified molecular markers related to drought resistance and water-use efficiency. 
Drought tolerance is given by a polygenic trait strongly influenced by the environment (FLEURY et al., 2010), and whose mechanisms are still not well understood. The breeding for this trait depends of the correct identification of the interest phenotype. Thus, it is fundamental to understand the networks that express the relationships among traits since they allow tracing strategies to obtain greater selection gains. Works on the relationship among the main traits or groups of alfalfa traits have been made available in the literature; however, only a few show the changes in the relationship among these traits under different water conditions. This work aimed to evaluate the relationship among traits related with yield and nutritive value of alfalfa genotypes grown under deficit and full irrigation conditions.

\section{MATERIAL AND METHODS}

Information about seventy-seven alfalfa genotypes evaluated in two cuttings were used (Table 1). The data came from an experiment carried out at Embrapa Pecuária Sudeste, located in the municipality of São Carlos, latitude $22^{\circ} 01$ ' 03 "S and longitude $47^{\circ} 53^{\prime} 27^{\prime \prime} \mathrm{W}$ ". The experiment was installed on November 2015, in a randomized block design with three replications. Each experimental unit consisted of four 4-m rows, spaced at $20 \mathrm{~cm}$. The plot area consisted of the two central rows, eliminating $0.5 \mathrm{~m}$ from each end. Irrigation management was applied by a central pivot system, based on the difference between evaporation and rainfall, according to Rassini (2002), and when plants reached $10 \%$ of flowering, the first cut was made to determine the production of dry matter biomass and other traits.

Since lower temperatures influence alfalfa performance (MONTEIRO et al., 1999), both cuttings were evaluated in a period in which alfalfa demonstrates similar response. While higher temperatures promote better development, the performance achieved from April to August is comparatively low. Data on the first cut evaluated in this study (under full-irrigation condition) was taken on May $9^{\text {th }}, 2016$ and corresponded to the seventh cut of the experiment. In July of 2016, irrigation was suspended to force water deficit. Data on the second cut (under water-deficit condition) was taken on August 12 $2^{\text {th }}, 2016$ and corresponded to the tenth cut. Each cut was considered as a distinct environment.

Table 1. Alfalfa accessions.

\begin{tabular}{llllll}
\hline Accession Genotype & Accession & Genotype & Accession & Genotype \\
\hline 1 & 5681 & 27 & GAPP 969 & 53 & ProINTA Luján \\
2 & ACA 900 & 28 & Gateado & 54 & ProINTA Mora \\
3 & ACA 901 & 29 & Kern & 55 & ProINTA Patricia \\
4 & Activa & 30 & LE N 1 & 56 & ProINTA Patricia \\
5 & Bacana & 31 & LE N 2 & 57 & ProINTA Super Monarca \\
6 & Bacana 1 & 32 & LE N 3 & 58 & Queen 910 \\
7 & Bar Pal 5 & 33 & LE N 4 & 59 & Rio Grande \\
8 & Bar Pal 10 & 34 & LPS 8500 & 60 & Ruano \\
9 & Baralfa 85 & 35 & Magna 601 & 61 & Ruano \\
10 & Bárbara SP INTA & 36 & Magna 804 & 62 & Sequel \\
11 & California 50 & 37 & Magna 860 & 63 & Sequel 2 \\
12 & CUF 101 & 38 & Magna 868 & 64 & Siriver 2 \\
13 & CW 1010 & 39 & Maitena & 65 & SPS 6550 \\
14 & CW 194 & 40 & Mecha & 66 & Trinidad 87 \\
15 & CW 620 & 41 & Medina & 67 & Verdor \\
16 & CW 830 & 42 & Milonga II & 68 & Verzi \\
17 & Diamond & 43 & MONARCA & 69 & Victoria SP INTA \\
18 & DK 166 & 44 & Monarca SP INTA & 70 & Villa \\
19 & DK 181 & 45 & P 30 & 71 & Winter \\
20 & DK 187 R & 46 & P 5715 & 72 & WL 1058 \\
21 & DK 192 & 47 & Patriarca & 73 & WL 516 \\
22 & DK 194 & 48 & Patricia & 74 & WL 525 \\
23 & Don Enrique & 49 & Pintado & 75 & WL 818 \\
24 & F 708 & 50 & PINTO & 76 & WL 903 \\
25 & Flórida 77 & 51 & Primavera & 77 & Crioula \\
26 & G 909 & 52 & ProINTA Carmina & - & - \\
\hline
\end{tabular}


Alfalfa is very sensitive to water deficit. Therefore, understanding the changes promoted by the water deficit in the relationship among traits of interest is fundamental. For the evaluation of these relationships, the following traits were assessed: Vigor (V: maximum, medium or low), measured one week after each cut; plant height $(\mathrm{PH}, \mathrm{cm})$, given by the average of five plants in the useful plot area when plants reached $10 \%$ of flowering; dry matter biomass (DMB, kg.ha ${ }^{-1}$ ), measured by cuts made whenever each genotype reached $10 \%$ of flowering or when basal shoots reached a mean height of 3-5 cm; stem-to-leaf ratio (S / L, \%), using the green matter during production cuts; dry matter percentage (DMP,\%); leaf and stem protein content (P); in-vitro dry matter digestibility (IVDMD); neutral detergent fiber (NDF); acid detergent fiber (ADF); and lignin (L).

Initially, a joint analysis of variance was performed as stated by the model:

$\mathrm{Y}_{\mathrm{ijk}}=\mu+\mathrm{B} / \mathrm{C}_{\mathrm{jk}}+\mathrm{G}_{\mathrm{i}}+\mathrm{C}_{\mathrm{j}}+\mathrm{GC}_{\mathrm{ij}}+\mathrm{e}_{\mathrm{ijk}}$

where: $\mathrm{Y}_{\mathrm{ijk}}$ is the genotype value of the $k$-th block, evaluated in the $i$-th genotype and $j$-th environment (environment is represented by the different cuttings); $\mu$ is the overall mean; $\mathrm{B} / \mathrm{C}_{\mathrm{jk}}$ is the effect of block $k$ within cut $j ; \mathrm{G}_{\mathrm{i}}$ is the effect of the $i$-th genotype; $\mathrm{C}_{\mathrm{j}}$ is the effect of the $j$-th cut; $\mathrm{GC}_{\mathrm{ij}}$ is the effect of the genotype $i \mathrm{x}$ cut $j$ interaction; $\mathrm{e}_{\mathrm{ijk}}$ is the experimental error associated with observation $Y_{\mathrm{ijk}}$, with $\mathrm{e}_{\mathrm{ijk}} \sim N\left(0 ; \sigma^{2}\right)$.

Individual analyses of variance within each environment were made to obtain estimates of phenotypic $\left(\mathrm{r}_{\mathrm{F}}\right)$ and genotypic $\left(\mathrm{r}_{\mathrm{G}}\right)$ correlations between traits, according to:

$$
\begin{aligned}
& \mathrm{r}_{\mathrm{F}}=\frac{\mathrm{COV}_{\mathrm{F}(\mathrm{xy})}}{\sqrt{\hat{\sigma}_{\mathrm{Fx}}^{2} \times \hat{\sigma}_{\mathrm{Fy}}^{2}}} \\
& \mathrm{r}_{\mathrm{F}}=\frac{\mathrm{COV}_{\mathrm{G}(\mathrm{xy})}}{\sqrt{\hat{\sigma}_{\mathrm{Gx}}^{2} \times \hat{\sigma}_{\mathrm{Gy}}^{2}}}
\end{aligned}
$$

where: $\operatorname{COV}_{\mathrm{F}(\mathrm{xy})}$ is the phenotypic covariance between traits $\mathrm{X}$ and $\mathrm{Y}$; $\hat{\sigma}_{\mathrm{Fx}}^{2}$ is the phenotypic variance of trait $\mathrm{X} ; \hat{\sigma}_{\mathrm{Fy}}^{2}$ is the phenotypic variance of trait $\mathrm{Y} ; \operatorname{COV}_{\mathrm{G}(\mathrm{xy})}$ is the genotypic covariance between traits $\mathrm{X}$ and $\mathrm{Y} ; \hat{\sigma}_{\mathrm{Gx}}^{2}$ is the genotypic variance of trait $\mathrm{X} ; \hat{\sigma}_{\mathrm{Gy}}^{2}$ is the genotypic variance of trait $\mathrm{Y}$;

Correlation network was used to express the relationship among phenotypic correlation coefficients between traits. Graphically, the closeness between traits are equivalent to the absolute correlation value between these traits. The line thickness was determined by applying a cut-off value of 0.60 ; thus, only correlations equal to or higher than 0.60 had their lines highlighted. Positive and negative correlations were highlighted in different colors (green and red, respectively).

Path analysis considering DMB as the dependent variable was performed by the model described above:

$\mathrm{DMB}=\beta_{1} \mathrm{~V}+\beta_{2} \mathrm{PH}+\ldots+\beta_{9} \mathrm{ADF}+\mathrm{p}_{\varepsilon}$

where: $\beta_{1}, \beta_{2}, \ldots, \beta_{9}$ are the estimators of direct effects of $\mathrm{V}, \mathrm{PH}, \mathrm{S} / \mathrm{L}, \mathrm{DMP}, \mathrm{L}, \mathrm{P}, \mathrm{DMD}$, $\mathrm{NDF}$, and $\mathrm{ADF}$ on $\mathrm{DMB} ; \mathrm{p}_{\varepsilon}$ is the analysis of residual effect. Thereby, the normal system of equations was employed to estimate the effects of each independent trait on $\mathrm{DMB}$, according to the following equation:

$\left[\begin{array}{ccc}1 & \cdots & \mathrm{r}_{\mathrm{V} ; \mathrm{ADF}} \\ \vdots & \ddots & \vdots \\ \mathrm{r}_{\mathrm{ADF} ; \mathrm{V}} & \cdots & 1\end{array}\right] \times\left[\begin{array}{c}\hat{\beta}_{1} \\ \vdots \\ \hat{\beta}_{9}\end{array}\right]=\left[\begin{array}{c}\mathrm{r}_{\mathrm{V} ; \mathrm{DMB}} \\ \vdots \\ \mathrm{r}_{\mathrm{ADF} ; \mathrm{DMB}}\end{array}\right]$

Determination coefficient $\left(\mathrm{R}^{2}\right)$ of path analysis was obtained by Equation 6:

$\mathrm{R}^{2}=\hat{\beta}_{1} \mathrm{r}_{\mathrm{V} ; \mathrm{DMB}}+\ldots+\hat{\beta}_{9} \mathrm{r}_{\mathrm{ADFDMB}}$

Residual effect $\left(\hat{p}_{\varepsilon}\right)$ of path analysis was obtained by:

$\hat{\mathrm{p}}_{\varepsilon}=\sqrt{1-\mathrm{R}^{2}}$

Before performing path analysis, a multicollinearity diagnostic was carried out against the correlation matrix, based on Montgomery \& Peck (2001). Software GENES (Cruz, 2016) was used to perform the statistical analyses (Cruz, 2016), as per procedures proposed by Cruz et al. (2012).

\section{RESULTS AND DISCUSSION}

Significant differences were found for most of the evaluated traits $(\mathrm{p}<0.05)$, except for $\mathrm{L}$ and $\mathrm{NDF}$, which allows inferring the presence of genetic variability among the genotypes (Table 2). Significant genotypes $x$ environments interaction $(G$ by $\mathrm{E}$ interaction) was identified only for $\mathrm{V}, \mathrm{PH}$ and $\mathrm{L}$, demonstrating that alfalfa genotypes had differential behavior for these traits when the irrigation system is changed. 
Table 2. Summary of joint analysis of variance for vigor $(\mathrm{V})$, plant height $(\mathrm{PH}, \mathrm{cm})$, dry matter biomass $\left(\mathrm{DMB}, \mathrm{kg} \cdot \mathrm{ha}^{-1}\right)$, stem-to-leaf ratio (S/L, \%), dry matter percentage (DMP, \%), lignin (L), leaf and stem protein contents (P), in-vitro dry matter digestibility (IVDMD), Neutral Detergent Fiber (NDF), and Acid detergent fiber (ADF) evaluated in 77 alfalfa cultivars in two environments.

\begin{tabular}{lclllll}
\hline \multirow{2}{*}{ Sources of variation } & \multirow{2}{*}{ DF } & \multicolumn{5}{c}{ Mean squares } \\
\cline { 3 - 7 } & & $\mathbf{V}$ & $\mathbf{P H}$ & $\mathbf{D M B}$ & $\mathbf{S} / \mathbf{L}$ & DMP \\
\hline Block/Environment & 4 & 0.22 & 527.18 & 381593.89 & 0.0412 & 21.1492 \\
Genotypes (G) & 76 & $1.77^{* *}$ & $346.91^{* *}$ & $615251.72^{* *}$ & $0.0412^{* *}$ & $0.7864^{* *}$ \\
Environments (E) & 1 & $16.76^{* *}$ & $21860.79^{* *}$ & $26454471.44^{* *}$ & $5.01^{* *}$ & $1.3983^{\text {ns }}$ \\
G x E & 76 & $0.2663^{* *}$ & $58.46^{* *}$ & $172029.85^{* *}$ & $0.0079^{\text {ns }}$ & $0.3994^{\text {ns }}$ \\
Residual & 304 & 0.11 & 29.32 & 91884.03 & 0.0096 & 0.4748 \\
\hline Mean & -- & 1.93 & 43.69 & 1602.07 & 0.6236 & 96.80 \\
CV (\%) & -- & 17.60 & 12.39 & 18.92 & 15.78 & 0.71 \\
\hline Sources of variation & $\mathbf{D F}$ & $\mathbf{L}$ & $\mathbf{P}$ & $\mathbf{I V D M D}$ & $\mathbf{N D F}$ & $\mathbf{A D F}$ \\
\hline Block/Environment & 4 & 9.6399 & 59.19 & 13.08 & 493.30 & 17.68 \\
Genotypes (G) & 76 & $0.3056^{\mathrm{ns}}$ & $12.32^{* *}$ & $3.29^{* *}$ & $7.91^{\text {ns }}$ & $3.42^{* *}$ \\
Environments (E) & 1 & $0.0002^{\text {ns }}$ & $29.37^{\text {ns }}$ & $468.09^{* *}$ & $1307.79^{\text {ns }}$ & $102.33^{\text {ns }}$ \\
G x E & 76 & $0.4205^{* *}$ & $1.19^{\text {ns }}$ & $1.01^{\text {ns }}$ & $6.54^{\text {ns }}$ & $1.89^{\text {ns }}$ \\
Residual & 304 & 0.2628 & 1.68 & 1.47 & 5.12 & 1.86 \\
\hline Mean & -- & 7.18 & 26.74 & 70.17 & 41.17 & 31.04 \\
CV $(\%)$ & -- & 7.14 & 4.86 & 1.73 & 5.50 & 4.40 \\
\hline
\end{tabular}

ns, ** and *: Not significant, significant by the F-test at the 0.05 and 0.01 probability level, respectively; G x E: Genotype $\mathrm{x}$ environment interaction; CV: coefficient of variation; DF: degrees of freedom.

In general, this analysis allows inferring that variability was not affected by the water management. Yet, it does not clarify how a genotype can overcome certain deficiencies by using alternative routes involving gene control of several other traits. For a better understanding, the correlation networks among the traits and the path analysis on DMB were made for each cut, aiming to identify auxiliary traits for indirect selection for fullirrigation and water-deficit conditions.

The correlation network was used to facilitate the interpretation of phenotypic and genotypic correlations in each cut. This procedure allows detecting some patterns that are hard to extract using other approaches (SILVA et al., 2016). Traits were listed in yield group (red circle) and nutritive value group (blue circle). The correlation network efficiency has already been reported by Ursem et al. (2008), Dileo et al. (2011), and Silva et al. (2016).

Although the magnitude is affected by the water availability, phenotypic correlations did not alter its sign (Figures 1 and 2). Figure 1 shows negative correlations between $\mathrm{V}$ and all its pairs (production group) between DMB and P and DMB and DMD. In addition, positive correlation between SL and DMB, as shown in this work, has already been reported by Julier et al. (2000) and Ray et al. (1999). Correlation magnitudes among traits of the nutritive value group were mostly low when compared with the others, except for $\mathrm{P}$ and DMD, which maintained some significant correlations. However, when the environmental effect was eliminated, the magnitude of the correlations between all traits changed. Traits of the nutritive value group showed significant correlations and of high magnitudes most of the time since they approached spatially of the others. Alfalfa breeding programs seek the reduction of fibrous components and lignin for they reduce forage digestibility. In this work, the main trait (DMB) correlated positively to the forage fiber components and negatively to vigor, indicating difficulties in the selection.

Simultaneous selection is one of the most promising strategies to overcome unfavorable correlations in alfalfa breeding. Santos et al. (2019) introduced an alternative to select alfalfa genotypes from forage yield and nutritive value traits. Artificial neural networks based on Taí index were successfully established to perform genotypes classification. The same strategy could be used to perform selection of alfalfa accessions grown under favorable and unfavorable water conditions.

Genotypic correlation network for the wellwatered cut kept the same sign of that of the phenotypic correlations, but had higher magnitude, 
indicating that environmental factors influence correlation estimates (Figure 1). This result was expected since the residual effect was removed when estimating these correlations. Lignin, which was not correlated with any other trait in the phenotypic network, showed a high negative correlation with DMP, revealing the true genetic association between these traits.

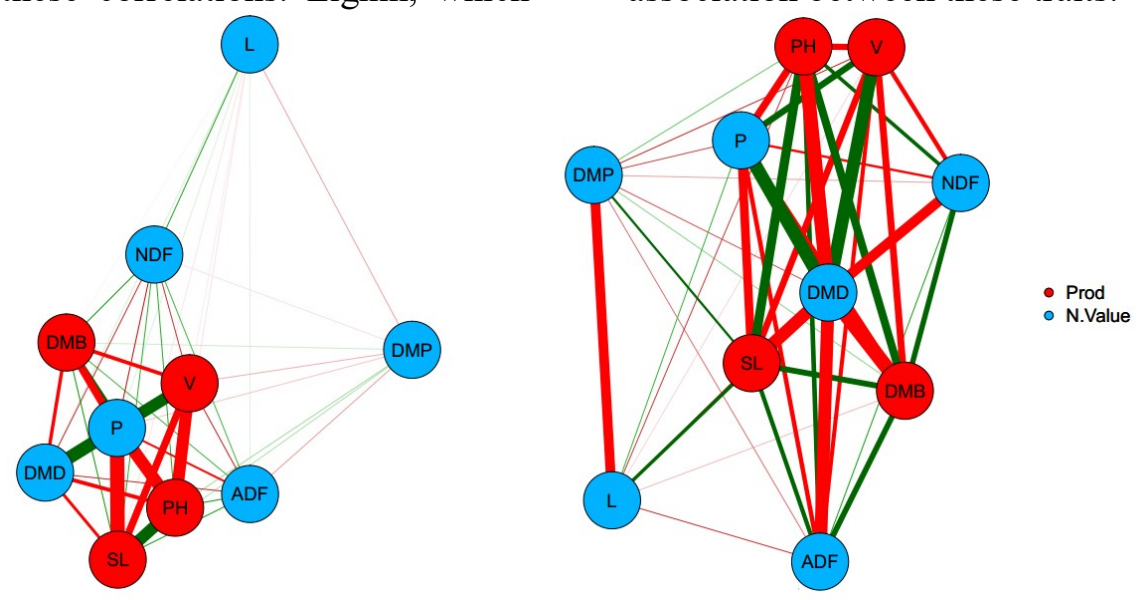

Figure 1. Phenotypic (left) and genotypic (right) correlation network of alfalfa traits under well-watered condition. Red and green lines represent negative and positive correlations, respectively. Line width is proportional to the strength of the correlation. Production group: vigor (V), plant height ( $\mathrm{PH}$, $\mathrm{cm})$, dry matter biomass (DMB, $\left.\mathrm{kg} \cdot \mathrm{ha}^{-1}\right)$, stem-to-leaf ratio ( $\left.\mathrm{S} / \mathrm{L}, \%\right)$. Nutritive Value group: dry matter percentage (DMP, \%), lignin (L), leaf and stem contents of protein (P), in vitro dry matter digestibility (IVDMD), Neutral Detergent Fiber (NDF), and Acid Detergent Fiber (ADF).

The water deficit impact in alfalfa traits is shown in Figure 2 results revealed negative and positive correlations similar to that of the cut collected under full-irrigation condition. However, the magnitudes changed, as observed between SL and $\mathrm{DMB}$, which had a significant correlation only under water-deficit condition. Alfalfa breeding programs aim at developing cultivars with high yield and digestibility. Moreover, they seek more leaves at the expense of stems since the former guarantees a high nutritive value due to the higher concentration of crude protein (BOTREL et al., 2001). The correlation between SL and DMD was negative, which makes the selection easier, especially in environments with water deficit. This is because the correlation value was higher under water-deficit conditions than full-irrigation conditions.

Although the water deficit changed the genotype correlation network, correlation signs remained the same when compared with the other correlation networks (Figure 2), indicating that the water deficit cannot change the correlation between traits, only its magnitudes. ADF, which previously had weak visible correlations with the groups of traits, stood aside in all groups of the genotype network due to the non-significance of this trait in the deficit environment.

Alfalfa breeding programs aim to develop superior genotypes regardless of water conditions.
Based on the estimated phenotypic and genotypic correlations for each cut, DMB correlated positively with SL and $\mathrm{PH}$ and negatively with $\mathrm{P}$ and $\mathrm{V}$. Evaluating DMB in a large set of genotypes at the final stages of a breeding program is timeconsuming. In addition, the environment highly influences this trait, requiring several cuts to identify the genetic superiority of a genotype. Therefore, identifying traits that can be used in indirect selection is fundamental. However, for this process to be efficient, the observed correlations between the DMB, as well as the cause and effect relation between the mean of the other traits must be verified.

Despite its relevance, phenotypic correlations may produce non-true results on the trait relationships and may not be a rightful cause and effect estimate (CRUZ et al., 2012). Path analysis, which examines the trait relationships and determines the effects of independent traits on the dependent one, was carried out to overcome this issue. However, path analysis execution requires the verification of the quality of the $X^{\prime} X$ matrix. Once multicollinearity is identified, the estimators' variances can attain extremely values, becoming inaccurate. Based on Montgomery and Peck (2001), the phenotypic correlation matrix had low multicollinearity since the condition number was lower than 100 in each cut. 

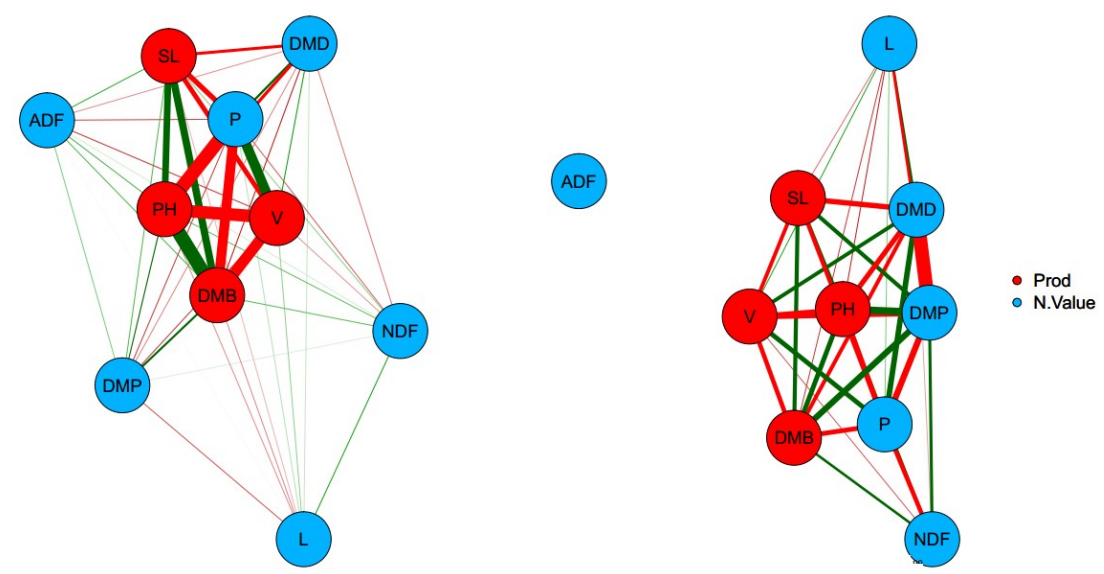

Figure 2. Phenotypic (left) and genotypic (right) correlation network of alfalfa traits under water-stressed condition. Red and green lines represent negative and positive correlations, respectively. Line width is proportional to the strength of the correlation. Production group: vigor $(\mathrm{V})$, plant height $(\mathrm{PH}$, $\mathrm{cm})$, dry matter biomass (DMB, $\left.\mathrm{kg} \cdot \mathrm{ha}^{-1}\right)$, stem-to-leaf ratio (S/L, \%). Nutritive Value group: dry matter percentage (DMP, \%), lignin (L), leaf and stem protein content $(\mathrm{P})$, in vitro dry matter digestibility (IVDMD), Neutral Detergent Fiber (NDF), and Acid Detergent Fiber (ADF).

The estimates of direct and indirect effects on DMB returned a coefficient of determination of $86.48 \%$ for the full irrigation condition (Table 3 ). However, when these effects were evaluated under water deficit, the coefficient of determination was low $(61.61 \%)$, and the effect of the residual variable was high (Table 4), indicating the importance of traits not included in this study in the determination of DMB under dry conditions. These results show that the selective accuracy in water deficit environments depends on the evaluation of more traits.

Table 3. Estimates of the direct and indirect effects of vigor $(\mathrm{V})$, plant height $(\mathrm{PH}, \mathrm{cm})$, stem-to-leaf ratio $(\mathrm{S} / \mathrm{L}$, $\%$ ), dry matter percentage (DMP, \%), lignin (L), leaf and stem contents of protein (P), in-vitro dry matter digestibility (IVDMD), Neutral Detergent Fiber (NDF), and Acid Detergent Fiber (ADF) on dry matter biomass (DMB, kg.ha ${ }^{-1}$ ) of 77 alfalfa cultivars under water-stressed condition.

\begin{tabular}{lclllllllc}
\hline Effect & $\mathrm{V}$ & $\mathrm{PH}$ & $\mathrm{S} / \mathrm{L}$ & $\mathrm{DMP}$ & $\mathrm{L}$ & $\mathrm{P}$ & $\mathrm{DMD}$ & $\mathrm{NDF}$ & $\mathrm{ADF}$ \\
\hline Direct on DMB & -0.2494 & 0.3041 & 0.2076 & 0.1224 & -0.2299 & -0.0260 & 0.0911 & 0.2996 & 0.0118 \\
Indirect through V & - & 0.2135 & 0.1711 & 0.1225 & -0.0655 & -0.2004 & -0.1468 & 0.0628 & 0.1226 \\
Indirect through PH & -0.2603 & - & 0.2208 & 0.1832 & -0.0824 & -0.2683 & -0.1974 & 0.1155 & 0.1349 \\
Indirect through S/L & -0.1424 & 0.1507 & - & 0.0874 & -0.0360 & -0.1439 & -0.1339 & 0.0591 & 0.1047 \\
Indirect through DMP & -0.0601 & 0.0737 & 0.0515 & - & -0.0506 & -0.0582 & -0.0361 & 0.0101 & 0.0378 \\
Indirect through L & -0.0604 & 0.0623 & 0.0399 & 0.0950 & - & -0.0389 & -0.0320 & -0.1292 & 0.0028 \\
Indirect through P & -0.0209 & 0.0229 & 0.0180 & 0.0124 & -0.0044 & - & -0.0163 & 0.0101 & 0.0116 \\
Indirect through DMD & 0.0536 & -0.0591 & -0.0588 & -0.0268 & 0.0127 & 0.0573 & - & -0.0295 & -0.0246 \\
Indirect through NDF & -0.0754 & 0.1138 & 0.0853 & 0.0248 & 0.1684 & -0.1167 & -0.0969 & - & 0.0292 \\
Indirect through ADF & -0.0057 & 0.0052 & 0.0059 & 0.0036 & -0.0001 & -0.0052 & -0.0032 & 0.0011 & - \\
\hline Total & -0.8212 & 0.8872 & 0.7414 & 0.6244 & -0.2880 & -0.8004 & -0.5716 & 0.3998 & 0.4308 \\
\hline
\end{tabular}

Coefficient of Determination $=0.8648$

Effect of the residual variable $=0.3676$

Regardless of the environment (Table 3 and 4), $\mathrm{PH}$ was one of the most promising traits for selection of alfalfa genotypes with higher DMB since it showed a high direct effect with the same sign of its phenotypic correlations. A comparable result was reported by Tuckak et al. (2008), who emphasized the importance of $\mathrm{PH}$ for indirect selection at early stages of alfalfa. In addition, evaluating genotype height is relatively simple, requiring less time and labor. However, $\mathrm{PH}$ exerts indirect effects of high magnitude on other variables. Thus, when selecting taller plants, genotypes with higher $\mathrm{DMB}$ and $\mathrm{S} / \mathrm{L}$, in addition to lower V, P, and DMD, will be selected. These results are not entirely interesting, as alfalfa breeding programs aim to select genotypes with 
greater vigor and higher crude protein content and lower $\mathrm{S} / \mathrm{L}$.

Table 4. Estimates of the direct and indirect effects of vigor (V), plant height (PH, cm), stem-to-leaf ratio (S/L, $\%$ ), dry matter percentage (DMP, \%), lignin (L), leaf and stem contents of protein (P), in vitro dry matter digestibility (IVDMD), Neutral Detergent Fiber (NDF), and Acid Detergent Fiber (ADF) on dry matter biomass (DMB, kg.ha ${ }^{-1}$ ) of 77 alfalfa cultivars under well-watered condition.

\begin{tabular}{llllllllll}
\hline Effect & $\mathrm{V}$ & $\mathrm{PH}$ & $\mathrm{S} / \mathrm{L}$ & $\mathrm{DMP}$ & $\mathrm{L}$ & $\mathrm{P}$ & $\mathrm{DMD}$ & $\mathrm{NDF}$ & $\mathrm{ADF}$ \\
\hline Direct on DMB & -0.1315 & 0.2614 & -0.1386 & 0.0154 & -0.1409 & -0.2182 & -0.1146 & 0.3685 & -0.0302 \\
Indirect through V & - & 0.1051 & 0.0938 & 0.0238 & 0.0051 & -0.1043 & -0.0857 & 0.0638 & 0.0708 \\
Indirect through PH & -0.2090 & - & 0.2078 & 0.0563 & -0.0156 & -0.2100 & -0.1703 & 0.1322 & 0.1537 \\
Indirect through S/L & 0.0988 & -0.1102 & - & -0.0259 & 0.0072 & 0.1165 & 0.0880 & -0.0675 & -0.0798 \\
Indirect through DMP & -0.0028 & 0.0033 & 0.0029 & - & -0.0032 & -0.0020 & -0.0000 & -0.0010 & -0.0035 \\
Indirect through L & 0.0055 & 0.0084 & 0.0073 & 0.0294 & - & -0.0105 & -0.0121 & -0.0753 & -0.0100 \\
Indirect through P & -0.1731 & 0.1753 & 0.1834 & 0.0287 & -0.0163 & - & -0.1780 & 0.1263 & 0.1345 \\
Indirect through DMD & -0.0747 & 0.0747 & 0.0728 & 0.0003 & -0.0099 & -0.0935 & - & 0.0579 & 0.0591 \\
Indirect through NDF & -0.1788 & 0.1863 & 0.1794 & -0.0235 & 0.1970 & -0.2133 & -0.1863 & - & 0.1618 \\
Indirect through ADF & 0.01625 & -0.0177 & -0.0174 & 0.0069 & -0.0021 & 0.0186 & 0.0155 & -0.0132 & - \\
\hline Total & -0.6493 & 0.6867 & 0.5916 & 0.1115 & 0.0212 & -0.7168 & -0.6435 & 0.5917 & 0.4563 \\
\hline
\end{tabular}

Coefficient of Determination $=0.6161$

Effect of the residual variable $=0.6196$

Results obtained with the path analysis and the phenotypic and genotypic correlation networks showed that, regardless of the water condition, no genotypes met the main desirable traits of alfalfa breeding programs. Thus, an alternative to bring together these desirable phenotypes would be the recombination of selected promising individuals. These promising individuals can be selected from selection indices, restricted or not. Artificial neural networks are an additional alternative since they have demonstrated high efficiency in performing alfalfa selection based on forage yield and nutritive value traits. These strategies will allow identifying the occurrence of transgressive segregants in the recombinant population.

\section{CONCLUSIONS}

The evaluation of alfalfa genotypes in different water regimes does not alter the signal of the correlations, only their magnitudes.

Selection indices should be used since more than one trait is relevant for selection efficiency under water deficit.

RESUMO: Este estudo objetivou avaliar a relação entre características relacionadas à produção e o valor nutritivo de genótipos de alfafa cultivados em condições de déficit e irrigação total. Setenta e sete genótipos de alfafa foram avaliados em dois cortes diferentes, o primeiro com irrigação total e o segundo com déficit hídrico. O delineamento experimental foi em blocos casualizados, com três repetições. As características avaliadas foram: vigor, altura de planta, biomassa de matéria seca, razão colmo-folha, porcentagem de matéria seca, teores foliar e foliar de proteína, digestibilidade in vitro da matéria seca, fibra em detergente neutro, fibra em detergente ácido e lignina. Houve interação significativa entre genótipos e ambientes para vigor, altura de planta e lignina. A correlação entre características e análise de trilha da biomassa da matéria seca foi realizada para cada corte, visando identificar características auxiliares para a seleção indireta. A disponibilidade de água não alterou as correlações fenotípicas e genotípicas, apenas suas magnitudes. Independentemente do ambiente, a altura das plantas é um dos caracteres mais promissores para a seleção de genótipos de alfafa com maior biomassa de matéria seca, uma vez que apresentou alto efeito direto no mesmo sentido de suas correlações fenotípicas. Entretanto, o coeficiente de determinação obtido pelo modelo aplicado à irrigação total foi superior àquele do ambiente com déficit hídrico, indicando a importância de variáveis não incluídas neste estudo na determinação da biomassa de matéria seca de alfafa em condições secas.

PALAVRAS-CHAVE: Medicago sativa. Análise de trilha. Correlações. Biomassa de matéria seca. 


\section{REFERENCES}

ANNICCHIARICO, P., BARRETT, B., BRUMMER, E. C., JULIER, B., AND MARSHALL, A. H. (2015). Achievements and challenges in improving temperate perennial forage legumes. Critical Reviews in Plant Sciences, 34, 327-380. https://doi.org/10.1080/07352689.2014.898462

ARSHAD, M., FEYISSA, B. A., AMYOT, L., AND AUNG, B. (2017). MicroRNA156 improves drought stress tolerance in alfalfa (Medicago sativa) by silencing SPL13. Plant Science, 258, 122-136. https://doi.org/10.1016/j.plantsci.2017.01.018

BOTREL, M. A., FERREIRA, R. P., ALVIM, M. J., AND XAVIER, D. F. (2001). Cultivares de alfafa em área de influência da Mata Atlântica no Estado de Minas Gerais. Pesquisa Agropecuária Brasileira, 36, 14371442. https://doi.org/10.1590/S0100-204X2001001100015

CABELLO, J. V., GIACOMELLI, J. I., GÓMEZ, M. C., AND CHAN, R. L. (2017). The sunflower transcription factor HaHB11 confers tolerance to water deficit and salinity to transgenic Arabidopsis and alfalfa plants. Journal of Biotechnology, 257, 35-46. https://doi.org/10.1016/j.jbiotec.2016.11.017

COMERON, E. A., FERREIRA, R. P., VILELA, D., KUWAHARA, F. A., AND TUPY, O. (2015). Utilização da alfafa em pastejos para alimentação de vacas leiteiras. In: FERREIRA, R. P., VILELA, D., COMERON, E. A., BERNARDI, A. C. C., AND KARAM, D. (Eds.), Cultivo e utilização da alfafa em pastejo para alimentação de vacas leiteiras (p. 13-16). Brasília: Embrapa.

CRUZ, C. D. (2016). Genes Software - extended and integrated with the R, Matlab and Selegen. Acta Scientiarum, 38, 547-552. https://doi.org/10.4025/actasciagron.v38i3.32629

CRUZ, C. D., AND REGAZZI, A. J. (2004). Modelos biométricos aplicados ao melhoramento genético. Viçosa: Editora UFV.

DILEO, M. V., STRAHAN, G. D., BAKKER, M., AND HOEKENGA, O. A. (2011) Weighted correlation network analysis (WGCNA) applied to the tomato fruit metabolome. PLoS ONE, 6, e26683. https://doi.org/10.1371/journal.pone.0026683

FERREIRA, R. P., BASIGALUP, D. H., VASCONCELOS, E. S., CRUZ, C. D., AND PEREIRA, A. V. (2008). Genética quantitativa e métodos de melhoramento em alfafa. In: FERREIRA, R. P., RASSINI, J. B., RODRIGUES, A. A., FREITAS, A. R., CAMARGO, A. C., AND MENDONÇA, F. C. (Eds.), Cultivo e Utilização da Alfafa nos Trópicos (p. 171-205). São Carlos: Embrapa Pecuária Sudeste.

FERREIRA, R. P., AND VILELA, D. (2015). Potencial de utilização da alfafa. In: Ferreira, R. P., VILELA, D., COMERON, E. A., BERNARDI, A. C. C., AND KARAM, D. (EDS.), Cultivo e utilização da alfafa em pastejo para alimentação de vacas leiteiras (p. 13-16). Brasília: Embrapa.

FISCHER, R. A., AND MAURER, R. (1978). Drought resistance in spring wheat cultivars I. Grain yield response. Australian Journal of Agricultural Research, 29, 897-907. https://doi.org/10.1071/AR9780897

FLEURY, D., JEFFERIES, S., KUCHEL, H., AND LANGRIDGE, P. (2010). Genetic and genomic tools to improve drought tolerance in wheat. Journal of Experimental Botany, 61, 3211-3222.

https://doi.org/10.1093/jxb/erq152

JULIER, B., HUYGHE, C., AND ECALLE, C. (2000). Within- and among-cultivar genetic variation in alfalfa: forage quality, morphology, and yield. Crop Science, 40, 365-369.

https://doi.org/10.2135/cropsci2000.402365x

MOLON, A., KHAJIDSUREN, A., MYAGMARJAV, U., AND VANJILDORJ, E. (2016). Comparative analysis of drought tolerance of Medicago sativa L. plants under stresses conditions. Mongolian Journal of Agricultural Sciences, 19, 32-40. https://doi.org/10.5564/mjas.v19i3.733 
MONTEIRO, A. L. G.; CORSI, M.; CARVALHO, D. D. (1999). Freqüências de Corte e Intensidades de Desfolha em Duas Cultivares de Alfafa (Medicago sativa, L). 1. Peso, Número, Produção Estacional e Dinâmica de Aparecimento das Brotações Basilares. Revista Brasileira de Zootecnia, 3, 446-452. https://doi.org/10.1590/S1516-35981999000300002

MONTGOMERY, D. C., AND PECK, E. A. (2001). Introduction to linear regression analysis. New York: John Wiley \& Sons.

RASSINI, J. B. (2002). Manejo da água na irrigação da alfafa num Latossolo Vermelho-Amarelo. Pesquisa Agropecuária Brasileira, 37, 503-507. https://doi.org/10.1590/S0100-204X2002000400012

RAY, I. M., TOWNSEND, M. S., MUNCY, C. M., AND HENNING, J. A. (1999). Heritabilities of water-use efficiency traits and correlations with agronomic traits in water-stressed alfalfa. Crop Science, 39, 494-498. https://doi.org/10.2135/cropsci1999.0011183X0039000200032x

SANTOS, I. G.; CRUZ, C. D.; NASCIMENTO, M.; FERREIRA, R. P. (2019) Selection index as a priori information for using artificial neural networks to classify alfalfa genotypes. Genetics and Molecular Research, 18, gmr18221. https://doi.org/10.4238/gmr18221

SILVA, A. R., RÊGO, E. R., PESSOA, A. M. S., AND RÊGO, M. M. (2016) Correlation network analysis between phenotypic and genotypic traits of chili pepper. Correlation network analysis between phenotypic and genotypic traits of chili pepper. Pesquisa Agropecuária Brasileira, 51, 372-377.

https://doi.org/10.1590/S0100-204X2016000400010

TUCKAK, M., POPOVIC, S., CUPIC, T., GRLJUSIC, S., BOLARIC, S., AND KOZUMPLIK, V. (2008). Genetic diversity of alfalfa (Medicago spp.) estimated by molecular markers and morphological characters. Periodicum Biologorum, 110, 243-249.

URSEM, R., TIKUNOV, Y., BOVY, A., BERLOO, R. VAN, AND EEUWIJK, F. VAN. (2008). A correlation network approach to metabolic data analysis for tomato fruits. Euphytica, 161, 181-193.

https://doi.org/10.1007/s10681-008-9672-y

VIANA, M. C. M., PURCINO, H. M. A., KONZEN, E. A., BOTREL, M. A., GIANASI, L.,

MASCARENHAS, M. H. T., AND FREIRE, F. M. (2004). Avaliação de cultivares de alfafa nas condições de Cerrado no estado de Minas Gerais. Pesquisa Agropecuária Brasileira, 39, 289-292.

https://doi.org/10.1590/S0100-204X2004000300013

ZHANG, T., YU, L. X., ZHENG, P., LI, Y., RIVERA, M., MAIN, D., AND GREENE, S. L. (2015). Identification of Loci Associated with Drought Resistance Traits in Heterozygous Autotetraploid Alfalfa (Medicago sativa L.) Using Genome-Wide Association Studies with Genotyping by Sequencing. PloS ONE, 10, e0138931. https://doi.org/10.1371/journal.pone.0138931

ZHANG, T, KESOJU, S., GREENE, S. L., FRANSEN, S., HU, J., AND LI, Y. (2017). Genetic diversity and phenotypic variation for drought resistance in alfalfa (Medicago sativa L.) germplasm collected for drought tolerance. Genetic Resources and Crop Evolution. https://doi.org/10.1007/s10722-017-0546-9 